\title{
Demystifying Intra-Legislative Conflicts in Nigeria: The Senate and the House of Representatives, 2007-2011
}

\author{
Peter Mba \\ Department of Political Science \\ University of Nigeria, Nsukka \\ ombah2006@yahoo.com
}

\section{Doi:10.5901/mjss.2014.v5n1p677}

\begin{abstract}
Since the inauguration of the Nigerian federal legislature in 2007, conflicts between the Senate and the House of Representatives have been on the increase. But they are seen as a necessary precondition of the learning democratic process of the time. This paper argues that partisan conflict and bickering within the legislature can occur not only when two or more political parties control the two chambers but even when one party does. This is defined by the pursuit of private interests. In spite of the strategic importance of the legislature, adequate and relevant explanation to the conflicts within the two chambers seems not to have been scientifically given. Political analysts and academics rarely focus attention on scientific explanation of the conflicts. The article examines the theoretical insight and argues that the Nigerian state shows a unique form of underdevelopment, dependence, and authoritarianism. Because of these situations, the state becomes means of production for those who controls it and intra-legislative relation becomes conflictive in nature.
\end{abstract}

Keywords: Legislature, Private Interest, Personal Ego, Senate, House of Representatives

\section{Introduction}

The third wave of democratization for political reform that spread across Africa and other parts of the world in the late 1980s and the mid-1990s culminated in the restoration of electoral pluralism in most of the countries of the continent including Nigeria in May 1999. This development led to the adoption of constitutional frameworks that guaranteed an important role in governance to the legislative arm of government. The particular form, content and scope which legislative power and mandate took differed from country to country. The structuring of its intra-legislative relations also differs. It is broadly shared that the legislature is the embodiment of the sovereignty of the people. In a democracy, the power of the people is exercised and expressed by the legislature. In this role, it was expected not only to make laws for the welfare of the generality of the populace but also to serve both as a democratically-empowered agency of restraint on the executive arm of government and a forum for the mobilization of popular participation in the broad governmental process. Representative legislative Houses at the federal and state levels of government in Nigeria were established by the 1999 constitution of the Federal Republic of Nigeria after a long period of military rule.

The legislature is the heart of any democratic government across the world. In most advanced democracies, the legislature is believed to be the closest organ of government to the people. However, this historic role played by the legislature has not attracted much attention, unlike the executive and the judiciary especially in the developing countries like Nigeria. This development according to Boyton and Kim (1975) 'may be attributed to the nature of legislative office that is neither the owner of the purse or the sword'. They further argued that legislatures have been key institutions in the development of the west for the past two hundred years. These are very considerable when compared with our knowledge of legislatures in other parts of the world. There seems to be little literature on legislature as an organ of government, legislative behavior and legislative conflicts within the legislature itself in Nigeria.

Compared with the advanced Western democracies, literature on Nigerian legislature is not as rich as those of the western world. Many reasons accounted for this. First, most of the available historical accounts of the role of colonial legislatures were actual documentation of the British. Second, most writings of Nigerian scholars focused their attention on the development of the Nigerian state and what it offers. Less attention was paid to the documentation of the actual performances and conflicts therein. In spite of the strategic importance of the legislature, adequate and scientific explanations to the conflicts within the two chambers in Nigeria. Political analysts and academics rarely focus attention on scientific explanation of the conflicts between the Senate and the House of Representatives in Nigeria. 
The rationale for the establishment of bicameral legislature in Nigeria was based on issues of ethnic suspicion, fear of political and economic domination at federal and state levels and uneven access to wealth among others. Consequently, the National Assembly was created with the wisdom of the great compromise. Sections of 48, 49 and 58 of the 1999 Constitution demonstrate this compromise. The compromised arrangement that put the National Assembly in place in 1999 envisaged an assembly with diverse interest and views which make conflict and disagreement inevitable. Undoubtedly, these conflicts were expected to arise in the process of legislation that concerns the welfare of Nigerians. This has not been so.

The strategic location of the legislature ensures its responsibilities for political representation of members' constituencies with respect to their disparate interests, the way it is expected to perform other legislative functions, including law making, oversight functions on the executive to ensure responsible and accountable governance, reformulation of the laws on administrative action with discretion to ensure adequate enforcement of rules, and to provide for a national integrity system by strengthening existing institutions committed to waging war against corruption. ${ }^{1}$ The 1999 constitution employed the principle of separation of powers as a cardinal feature for the operation of both constitutional democracy and presidentialism in the country. In fact, section 4 (1) of the 1999 constitution states" the legislative powers of the Federal Republic of Nigeria shall be vested in a National Assembly for the federation which shall consist of a Senate and House of Representatives". ${ }^{2}$ Section 4(2) also states that the National Assembly shall have power to make laws for the peace, order and good government of the Federation or any part thereof with respect to any matter included in the Exclusive Legislative List set out in Part 1 of the Second Schedule to this constitution.

However, the operation of the legislature has been characterized by conflicts, confrontations, and deadlocks between the Senate and the House of Representatives especially between 2007 and 2011. This is because different cadres of political men demonstrate their involvement in politics in different methods and ways. Their modes of participation are likely to vary according to the socio-psychological factors which help to define them and the nature of the political system as well as the history of political socialization and culture that they go through. Prevalent explanations see the conflicts between the Houses as the unavoidable teething problems of a nascent democracy. Conflict between the Senate and the House are not merely the result of the learning process of the new democratic process. It is assumed that legislators will realize the co-ordinate characters of the Senate and the House of Representative powers and, therefore, the desideration of cooperative work. There are other reasons advanced that sound rhetoric favouring one chamber or the other and this has accumulated in both the popular press and the writings of political scientists. Much of this rhetoric revolves around the legitimacy of disagreement between the Senate and House of Representatives. In many publications by scholars, there are opinions that the platform of a party winning the majority in each chamber usually breeds disagreement and conflict between the two chambers. Usually, if the same party wins a majority in legislature, the gap between the chambers output is often held to reflect the extent of disagreement between the members. It is expected that conflicts will be common between the two chambers when different parties are in the majority in both chambers. In this case, issues are usually seen from different views and perspectives.

Increasingly this explanation is deemed to be an optimist's dream. Political Scientists argue that conflicts will be common between the two chambers when different parties are in the majority in both chambers. In this case, issues are usually seen from different views and perspectives and neither party is willing to abandon its position. Usually, conflicts and disagreements are based on policy disagreements. Conflicts based on different positions on bills and policies are not, therefore, new but in the Nigerian case they are not based on issues and policies.

The 1999, 2003, and 2007 general elections made the Peoples Democratic Party (PDP) pivotal in the National Assembly. The National Assembly is not divided by electoral results. Nigerians expected that acting upon their strengthened bargaining position in the National Assembly, that rancorous and conflictive relationships could be reduced to its barest minimum. It was assumed that a party with a majority in the two chambers of the legislature and controls the executive will then be able to carry out its platforms. This has not been the case.

However, in a country such as Nigeria where economic development is at the lowest level, the motivating factor has always been private interest, personal ego and sectional interest as the driving force of politics and of the feuds between the two chambers. Within two years of the present civilian administration, two Senate Presidents have been impeached, one Speaker of the House of Representatives have been disgraced out of office, his successor has come close to impeachment at least twice and there have been financial scandals/probes in both the Senate and the House of Representatives. Many legislators see the proverbial "hand of Esau and voice of Jacob" in these events. Consequently, many allegations have been made. Accusing fingers have been pointed at the former President Obasanjo for bribing some legislators to destabilize the National Assembly. 
An examination of intra-legislative conflict between the two chambers between 1999 and 2009 reveals that despite the Peoples Democratic Party (PDP) controlling the majority seats in the two legislative bodies, the overall level of conflicts has been on the increase. Recent examples include the reception programmes planned for the President of Finland, Tarja Kaarina Halonen,who was to visit the National Assembly as part of her engagements in Nigeria, the passage of 2008 Appropriation and the bickering between the two chambers over which of them will host the joint sitting for the 2010 budget.

This paper, therefore, aims to critically evaluate how the pursuit of private interest and massaging of personal ego of members of the two chambers reinforce the conflictive and rancorous relationships within the National Assembly. This strand of analysis is central in framing our problematique of the conflict between the two chambers. In reality, intralegislative conflicts are not as a result of a different party controlling the two legislative arms, learning process and on the issue of principle and dedication to good legislation by standing on both sides of public interest, but, however, reflect a great deal of pursuit of private and selfish interests. Secondly using primary data collected through structured questionnaire, semi-structured interview and relevant documents (such as newspapers, magazines, etc), the paper tends to answer the question-Does the intra-legislative conflictive relations between the Senate and the House of Representatives be traced to pursuit of private interests and massaging of personal ego?

\section{The National Assembly in the Fourth Republic}

Since the return to democratic governance in Nigeria in 1999, intra-legislative relations at the federal level have witnessed three phases:

1. The radical phase (1999-2003)

2. The conservative phase (2003-2007)

3. The ego-centric phase (2007-date)

The first phase witnessed immense internal unity which helped it to ward off executive interferences in the running of their affairs. They were vibrant and radical right thinking members who understand their mission there. Although executive-legislative relations were conflictive in nature and character, relations between the Senate and House of Representatives were cordial. In this phase, the federal legislature was saddled with the task of maintaining internal cohesion and stability in warding off the presidential interference in the election and appointment of principal officers of the assembly and being a check on the excesses of the executive. During this phase, two Senate Presidents were impeached; one Speaker of House of Representative was also disgraced out of office. The first Senate President, Evan Enwerem was removed from office because he was alleged to be President Obasanjo's stooge, sponsored and planted by him. The Speaker of the House of Representatives was removed based on certificate racketeering and was equally accused of being sponsored by the President.

The second phase is what we called conservative phase or what we may call 'rubber stamp' legislature, in which the President because of his previous experience with the National Assembly carefully ensured that the majority of the radical members were not reelected into the federal legislature. The fraudulent elections of 2003 made that mission possible for the President. It was constituted by members of "Say Yea, the Eyes have it" or what may be called "yes members" except of course the tenure elongation saga which they overwhelmingly rejected due to serious internal and international pressure. This phase lacked the vibrancy of the first phase as it ceased to be a check or watch dog on the excesses of the executive.

The third phase has the majority of the second phase as members of the federal legislature as well as few new members. Ever since its inception in 2007, its goals have been to pursue parochial private interests of members of each chamber. From 2007 to date, internal conflicts and rancorous relations become the decisive factor in the federal legislature. Essentially, their focus has moved from a watchdog role to self-aggrandizers who seek nothing but private interest perpetuated by the quest for money and wealth.

\section{A Methodological Note}

This study was designed to employ multiple data gathering strategies, both primary and secondary. First, it is based on desk review involving examination of important literature on the subject. Secondly, a comprehensive questionnaire and interview section was designed to enable respondents of both federal and state legislators to freely express their opinions on the intra-legislative conflicts in Nigeria. A sample size of 400 respondents was projected for the study to be drawn from federal and state legislators, lawyers and members of civil society organizations. Only 210 were returned and 
used for our analysis for measuring the relationship between private interest and intra-legislative conflict in Nigeria. We did this to test our hypothesis based on the claim that the pursuit of private interest and personal ego increases conflicts between the Senate and the House of Representatives. The selection of these respondents was purposive. In terms of distribution, the six geo-political zones were used, Port Harcourt, Enugu, Lagos, Kaduna, Markurdi, Yola and Abuja. These reflect state capitals in the geo-political zones of the country. Finally, purposive samples of respondents concerning the objectives were taken.

Responses from the questionnaire were coded and analyzed using the Statistical Package for the Social Sciences (SPSS). Descriptive analysis--- frequencies cross tabulations and chi-square results were generated with SPSS for the study.

\subsection{Theorizing Intra-Legislative Conflicts in Nigeria}

One basic concept of modern democracy is derived from the theory of separation of powers as propounded by Baron Montesquieu. This theory has been assumed to be the cornerstone principle of democracy in the last three centuries. In 1748, Montesquieu published the Spirit of Laws (Esprit de Lois) in which he reformulated an ancient idea in political theory. In Book XI of the Spirit of Laws, Montesquieu ascribed liberty in England to the separation of legislative, executive, and judicial powers, and to the balancing of these powers against each other. ${ }^{3}$ In medieval European constitution making, the idea of division of powers came to be a counterforce against the divine sovereign powers claimed by monarchs. And in England, the long struggle between the crown and both parliaments and courts of common law, which climaxed in the Glorious Revolution of 1688 , underscored the importance of separation of powers and checks and balances.

The genius of Montesquieu lay in reformulating an idea connoting a political balancing of economic and social interests into a system of legal checks and balances between parts of a constitution. Montesquieu conceptualizes a system of government in which each traditional arm of government (i.e. executive, legislative, and judiciary) maintains clear and distinguished functions of its own as allotted to it by the constitution with checks and balances from the other two arms. American federalists later adopted the propositions of Montesquieu especially Madison, as the organizing framework of the American constitution. The constant aim is to divide and arrange the branches of government in such a way that each may be a check on the other to check tyranny and conflict between the arms of government. Although the idea to separate and co-ordinate the power of the three arms of government has been a major principle of liberal democratic constitution making for many years, political scientists, often neglect its organic connection to competitive capitalism. Consequently, there is no attempt to theorize its general and fundamental basis especially the relations between the two chambers of the legislature.

Therefore, a fundamental understanding of separation of powers especially within the legislature and the changes it has undergone in specific countries lies in the character of capitalistic production and the capitalist state. Being a market oriented commodity driven system, the capitalist society invariably evolves a legislative force seemingly standing above society and appearing as the guarantor of the collective interests of the people. In the West, separation of powers was particularly important at the phase of competitive capitalism for it served to balance conflicting interests of fractions of the ruling class, for instance, the estates in medieval Europe. Because these interests were usually inscribed in the arms of government, the liberal state which corresponds to competitive capitalism, appears as non-arbitrary, impartial and therefore capable of guaranteeing both the interests of the dominant and dominated classes and factions.

From the preceding analysis, two critical points have to be made about intra-legislative conflicts from competitive capitalism and the liberal state. First, the political function of the state, which consists of exercise of legitimate violence and the reproduction/inculcation of the dominant ideology, takes precedence over its economic function. Indeed, the liberal states rarely intervened directly in the market. Second, the legislature, which symbolizes popular power, tends to be dominant over the executive and administration. This dominance arose because parliament as the sanctuary of law and legislative power incarnated general norms whose universal and formal character constituted the essential features of modern law. However, the legislature has become a declining and fragmented body trying with little success to cope with the expansive and over dangerous power of a stronger institution, the executive.

The Nigerian state as well as its ruling class which emerged at the phase of monopoly capitalism, as a periphery variant of it, has also been shaped by it, and this class focused attention exclusively at the level of superstructure and were nowhere controlling the system of production on which politics has been anchored as in the advanced capitalist states. What followed was that the class resorted to the use of state power to secure their economic base and built an economic empire for itself. The state, therefore, becomes an instrument for the achievement of personal interests. Since 
every member of the National Assembly uses the state power for that purpose, conflicts become inevitable and the intralegislative conflict in Nigeria can be located in this context. Because the state power has assumed a major means for capital accumulation, the ruling class while pursuing its private economic interests so often do clash with one another, the implication being multiplication of conflicts in the process of pursuing these private interests with total disregard to the public/national interests. The state tends to be all-powerful. Since this state is all-powerful and there are few safeguards on how its tremendous power is to be used in a moderate and civil manner, groups and individuals such as the members of the legislature take a great deal in controlling it. In the circumstance, competition among these various groups of people to control its power is cut-throat in nature and there is unprecedented primacy of politics since to be excluded from this power is utter ruin and to be included is lasting prosperity.

\section{Fig. I: $A$ Theory of Private Interest and Legislative Conflicts}

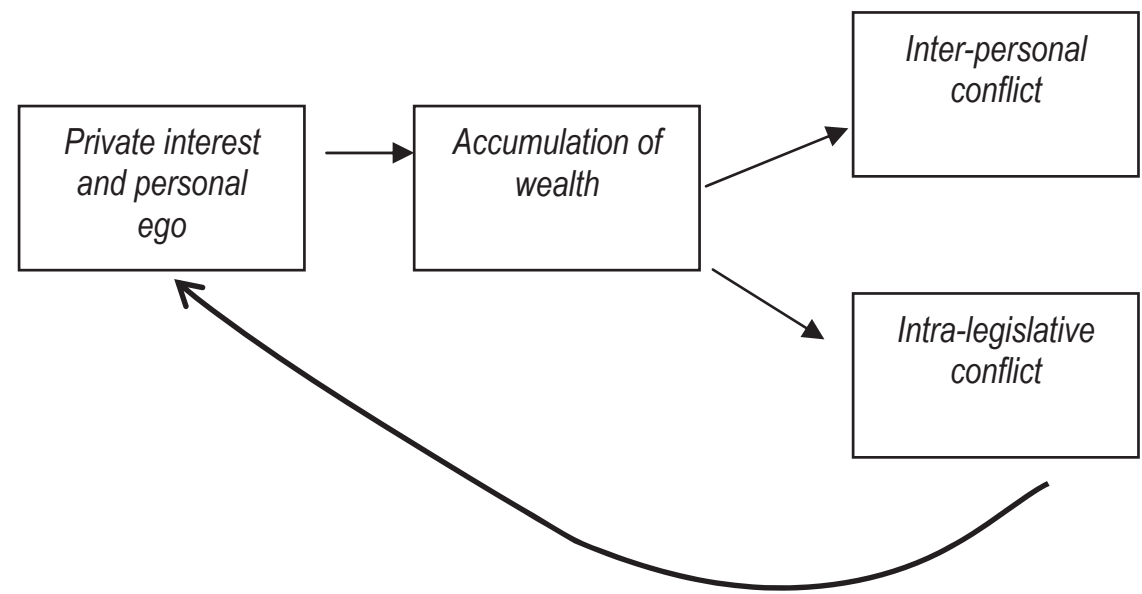

\section{The Role of Private Interest and Personal Ego in Federal Intra-Legislative Conflict in Nigeria}

Since the return of democracy in Nigeria in 1999, four legislative Assemblies have been elected at both the national and sub-national levels: these were in 1999-2003, 2003-2007, 2007-2011 and 2011-2015 respectively. The members of the National Assembly were elected to make laws for the smooth running of the country including legislating for peace, order and good governance of the federation.

However, the leadership of the National Assembly often demonstrates propensity for conflicts between the two legislative chambers. This is because the role of the state in Nigeria is becoming increasingly obvious as a means for the achievement of private interest and personal ego. The condition of the country's underdevelopment means that political or state power offers opportunities for public officeholders to rise above the general poverty and squalor that pervades the entire Nigerian society. Perhaps, political power has served the private interest of the members of the National Assembly and has been used to foster private interest for the benefits of their families, friends and praise singers. State power is probably the easiest means for which one enriches oneself for whoever has acquired it.

Besides, the state has become a means of production for those who have acquired it and have control over its resources. State power becomes parceled out and personal interests become deflected as collective interest. This primacy of politics becomes even worse as economic resources reduce or become more concentrated in few hands, usually as result of neo-liberal economic policies at home, and a global economy in which the periphery is profoundly disadvantaged. As this happens, the social base of the peripheral capitalist state becomes even narrower, further intensifying the primacy of politics and disrespect for moderating rules. The state remains a state of private and sectional interests rather than a representative of the collective interests of the people. The state exists as prebends parceled out to various private and sectional interests. Consequently, politics becomes fiercely prebendal as private and sectional interests engage themselves in fatal contest for increasing and defending their share of the powers of the state and the enormous economic advantages therefrom. ${ }^{4}$ In fact the Nigerian state presents the following characteristics namely: absolutism, arbitrariness, absence of moderating rules, low legitimacy and lack of unity of powers. This process has 
dominated the present conflict between the Senate and House of Representatives. The relations between the two legislative bodies are therefore, essentially relations of conflict based on competitive materialistic interest and personal ego.

In understanding what private interest denotes, it is important to begin with the understanding of the meaning of public interest or national interest. This will help us in conceptualizing private interest. Simply put public interest refers to the common well-being or general welfare. It covers the whole range of subjects from sovereignty, unity and security of state to communal amity, economic stability, and the standard of decency and morality. In a nutshell, public interest involves sovereignty, welfare, unity, faith, peace, and progress. This is central to policy debates, politics, democracy and the nature of government itself. In other words, public interests include factors such as ensuring the efficient and effective running of public services and an interest in ensuring the administration of justice. In this sense the public is a group of non-specific persons (Nigerians outside the government). They are persons that share an interest as they consider themselves as potential members of a non-specific group, abstracting from their particular position and private interest. This is related to Rousseau's concept of the General Will. Thus the contrasting view of public interest is private interest. What is not public interest is private interest and private interest is motivated by a narrow and parochial concept of self interest: wealth, fame and power. If there is conflict between the public and private interest amongst government decision-makers, the public interest suffers. A country where public interest is dominant, both leaders and the citizenry work towards achieving the public interest which is their common objective. But when leaders pursue private interest, resources earmarked for public interest are diverted to private use. The pursuit of private interest by the members of the National Assembly makes intra-legislative conflict inevitable, and this is why corruption is endemic in Nigeria.

What follows this is personal ego which has become the moving force for the actions of the members of the House of Representatives and the Senate. The word, ego is taken directly from Latin where it is the normative of the first person singular personal pronoun and is translated as "I myself" to express emphasis. Ego in philosophical terms means one's self. It is used to mean a sense of self. It is an inflated feeling of pride in superior to others ${ }^{5}$ and this feeling has taken control and crossed the line into arrogance, obnoxiousness and overactive need to be recognized and to be in charge in the business of the two houses in the process of law making in Nigeria. The ego becomes the driving force for the members of two chambers for primitive accumulation which is devoid of morality while satisfying their material quest.

To be sure, a Nigerian Senator earns more than the American President, Barrack Obama. The president of the United States earns an annual salary of $\$ 400,000$ (N64.156m), including a $\$ 50,000$ expense allowance making the president the highest paid public servant in the US. The $\$ 400,000$ includes everything and $\$ 350,000$ out of which is taxable. ${ }^{6}$ In the same manner, while the minimum wage is $\$ 1,257$ (N191, 667), a US lawmaker earns $\$ 15,080$ (N2.3m) per month. In the United Kingdom, a lawmaker earns $\$ 8,686$ (N1.3m) monthly while the gross national minimum wage is $\$ 1883$ (N283, 333) per month. ${ }^{7}$ In 2011, Nigerian Senate President earns N560m $(\$ 3.7 \mathrm{~m})$ per annum. The Speaker of House of Representatives earns $\mathrm{N} 225 \mathrm{~m}(\$ 1.51 \mathrm{~m})$ per annum, while national minimum wage in Nigeria is N7, 500. Other Senators earn N225m $(\$ 1.5 \mathrm{~m})$ per annum excluding other monthly allowances such as housing, vehicle maintenance, entertainment, utility, wardrobe, personal assistance, domestic staff, recess allowance and newspaper allowance for members of the two chambers.

\section{Additional Monthly Allowance for National Assembly Members}

$\begin{array}{lcc} & \text { Senate } & \text { Reps } \\ \text { Housing Allowance } & \mathrm{N} 4.96 \mathrm{~m} & \mathrm{~N} 3.96 \mathrm{~m} \\ \text { Vehicle Maintenance } & \mathrm{N} 1.86 \mathrm{~m} & \mathrm{~N} 1.485 \mathrm{~m} \\ \text { Entertainment } & \mathrm{N} 0.74 \mathrm{~m} & \mathrm{~N} 0.594 \mathrm{~m} \\ \text { Utility } & \mathrm{N} 0.74 \mathrm{~m} & \mathrm{~N} 0.594 \mathrm{~m} \\ \text { Wardrobe } & \mathrm{N} 0.62 \mathrm{~m} & \mathrm{~N} 0.494 \mathrm{~m} \\ \text { Personal Assistance } & \mathrm{N} 0.62 \mathrm{~m} & \mathrm{~N} 1.485 \mathrm{~m} \\ \text { Domestic Staff } & \mathrm{N} 1.86 \mathrm{~m} & \mathrm{~N} 1.485 \mathrm{~m} \\ \text { Recess Allowance } & \mathrm{N} 0.25 \mathrm{~m} & \mathrm{~N} 0.198 \mathrm{~m} \\ \text { Newspapers } & \mathrm{N} 0.37 \mathrm{~m} & \mathrm{~N} 0.297 \mathrm{~m} \\ \text { Total } & \mathrm{N} 12.02 \mathrm{~m} & \mathrm{~N} 9.603 \mathrm{~m}\end{array}$

Source: BusinessDay, 21 June, 2010:1 
In 2011 each member of the Senate earned N2.48m every month while his counterpart in the House of Representatives earned N1.98m per month. In the same year the lawmakers sought to increase their allowances by hundred percent. Consequently, a Nigerian Senator now takes the following as salary and allowances:

- $\quad$ Basic Salary: (BS)

$\mathrm{N} 2,484,245.50$

- Hardship Allowance: $\quad 50 \%$ of basic salary N1, 242,122.75

- Constituency Allowance: $200 \%$ of BS N4, 968,509.00

- $\quad$ Furniture Allowance: $300 \%$ of BS N7, 452,736.50

- Newspaper Allowance: $50 \%$ of BS N1, 242,122.75

- Wardrobe Allowance: 25\% N621, 061.37

- Recess Allowance: $10 \%$ N248, 424.55

- Accommodation: $200 \%$ N4, 968,509.00

- Utilities: 30\% N828, 081.83

- $\quad$ Domestic Staff: 35\% N863, 184.12

- $\quad$ Entertainment: 30\% N828, 081.83

- $\quad$ Personal Assistance: 25\% N621, 061.37

- Vehicle Maintenance Allowance: 75\% N1, 863,184.12

- Leave Allowance: $10 \%$ N248, 424.55

- $\quad$ Severance Gratuity: 300\% N7, 452,736.50

- Motor Vehicle Allowance: 400\% N9, 936,982.00

- Total per month N29, 479,749.00 by 109 Senators. ${ }^{8}$

The National Assembly has been by the foregoing an Assembly for looting. There is serious doubt whether these have been slashed by $20 \%$ as requested by the late President, Umaru Yar'Adua.

Comparatively, the US Senate Leader earns $\$ 193,400$ per annum as salary. His counterpart in the House of Representatives earns $\$ 208,100$ as salaries and allowances. In the UK, the Leader of Lords earns $\$ 136.031$ per annum and the Speaker of House of Commons earns \$136.031 per annum. Currently, the Senate President in Nigeria earns $\mathrm{N} 250 \mathrm{~m}$ quarterly or N83.33m per month. ${ }^{9}$ Senate Deputy President gets $\mathrm{N} 150 \mathrm{~m}$ per quarter or N50m a month. What this means is that a federal legislator in Nigeria is paid more than double what a member of British legislator earns at least 8 times as much as an American legislator earns per annum and more than 3 times the American President. This jumbo pay has not been translated into quality legislations that touch the lives of Nigerians positively. Rather the conflicts between the two branches of the legislature have led to the decline of passage of bills especially under the period in review.

Table 1: National Assembly and Bills Passed

\begin{tabular}{|c|c|c|c|c|c|}
\hline \multicolumn{6}{|c|}{$\begin{array}{l}\text { Has the conflictive relations between the Senate and House of Representatives led to a decline in } \\
\text { the number of legislations passed? }\end{array}$} \\
\hline & & Frequency & Percent & Valid Percent & Cumulative Percent \\
\hline \multirow[t]{4}{*}{ Valid } & no response & 2 & 1.0 & 1.0 & 1.0 \\
\hline & Yes & 190 & 90.5 & 90.5 & 91.4 \\
\hline & No & 18 & 8.6 & 8.6 & 100.0 \\
\hline & Total & 210 & 100.0 & 100.0 & \\
\hline
\end{tabular}

\section{Source: Data from fieldwork}

From Table one above, it is the general opinion of our respondents that such conflicts between the two chambers do not encourage passage of bills for the benefit of many Nigerians. In fact, coming against the backdrop of reports that only 16 bills were passed, including the statutory yearly budget since June 2007 when the sixth session was inaugurated the view that the National Assembly has not lived up to the expectation of Nigerians is pervading. ${ }^{10}$ Out of 210 respondents, 
190 representing $90.5 \%$ was of the view that conflicts between the two chambers led to the decline in the passage of bills. Only 11 of the bills have received presidential assent.

Table 2 below shows that pursuit of private interest is rife and pervasive among members of the National legislature.

\section{Table 2: Conflict between the Senate and the House}

\begin{tabular}{l} 
Do you think that the conflict between the Senate and House of Representatives on the chairmanship of Joint Committee \\
on the review of the 1999 constitution is predicted on? \\
\hline
\end{tabular}

Source: Data from fieldwork

Out of 210 respondents 189 representing 90\% was of the opinion that the conflict between the two houses is predicated on the pursuit of private interests. A country where private interest is dominant, both the leaders and the citizens rarely work towards achieving the national interest which supposed to be their common goal. For national interest to be achieved, the leaders have to play vital roles, especially being selfless, since they are the ones that enact laws with which the country is governed. In this kind of country, where leaders pursue private interest, nothing works since their concern is what they can grab from the system. This encourages endemic corruption and ineptitude since money budgeted for development will be diverted to private bank accounts.

Currently, the global capitalism is cumulatively making the situation worse. It has done this by creating two competing legislative chambers. They view their positions from purely private, sectional and partisan considerations. The dominant philosophy of the members of the National Assembly is oriented towards acquiring, grabbling and accumulating wealth thereby creating antagonistic relationship between each other. Thus, government in Nigeria, whatever their outward forms, is merely a reflection of underlying economic forces, primarily the pattern of ownership of the "Nigerian State". The constitution of 1999 for both theoretical and practical reasons anticipates a legislature that largely shared powers but sometimes exclusive. However, the calculation of the House members is that the Senate is playing a game of economic exclusion, hence the face-off between the two Houses. The bribery scandals rocking the National Assembly bear testimony to this fact of over-bearing private interests as the driving force of the feuds between them. The legislature which is supposed to be embodiment of universal reason and collective will of the people-nation is increasingly becoming an assembly of corruption.

Currently, Nigeria Senate President earns 560 million Naira $(\$ 3.7 \mathrm{~m})$ per annum. The Speaker of House of Representatives earns 225million Naira (\$1.5) per annum as salary. However, the US Senate Leader earns $\$ 193,400$ per annum as salary. His counterpart in the House of Representatives earns $\$ 208,100$ per annum as salaries and allowances. In the UK, the leader of the House of Lords earns $\$ 136.031$ per annum and the Speaker of the House of Commons earns $\$ 136.031$ per annum. In Nigeria, other members of the Senate earns 225 millions $(\$ 1.5 \mathrm{~m})$ each per annum. In US Senators earn $\$ 174,000$ each per annum, and in the UK each Member of the Parliament earns $\$ 94.558$ per annum. Currently in Nigeria, each member of the Senate earns 2.48million Naira every month and the members of the House of Representatives earn 1.98million every month. Recently the Law Makers have sought to increase their allowances and salaries by 100 percent. This explains why the rancorous relationship between the two chambers has been enormous. Recently, the Governor of Central Bank of Nigeria, Mallam Lamido Sanusi stated that $25 \%$ of the federal spending was being consumed by the National Assembly. ${ }^{11}$ The federal government overhead for 2010 was 536.2 billion naira while National Assembly overhead was $136,259,768,102$ which are exactly $25.41 \%$ of the federal government. The following evidence bears testimony to the claims that the intra-legislative conflicts in Nigeria are based on personal interest and massaging of personal ego by members of the two chambers. 


\subsection{The walk-out from Minna Retreat}

The current feud between the Senate and the House of Representatives stems from the above analysis. The walk-out of the House of Representative members from the retreat of the Joint Committee on Constitutions Review in protest against the Deputy Speaker of being designated as Deputy Chairman, and not as co-chairman of the committee suggests that personal overrides national interest. The walk-out suggests that it is beyond co-piloting the affairs of the committee on review of the 1999 constitution. Otherwise, it is hard to believe that the House of Representatives can trivialize a matter of great national importance and deep concern to the country. It is difficult to see how proceedings at a meeting can be effectively directed by two persons as co-chairman with equal powers of control. There just cannot be two captains in one ship. The impression created by the wrangling over a matter that should not be the subject of controversy warranting a walk-out is that the House members of the Joint Committee are more interested in the perquisites of a co-chairman allowance, jeeps, luxury hotel suite and such other privilege befitting the dignity of a co-chairman of the committee - than in delivering to the Nigerians a reformed constitution better suited to their needs for good governance..$^{12}$ Because of the difficulty mentioned above, the progress and success of a constitution review exercise is more likely to be impeded than facilitated if meetings of the committee are presided over by two persons as co-chairman.

Table3: Which Chamber should be blamed for Generating Conflicts?

\begin{tabular}{|l|l|r|r|r|r|}
\hline \multicolumn{2}{|c|}{} & Frequency & Percent & Valid Percent & Cumulative Percent \\
\hline \multirow{3}{*}{ Valid } & no response & 23 & 11.0 & 11.0 & 11.0 \\
\cline { 2 - 7 } & Senate & 17 & 8.1 & 8.1 & 19.0 \\
\cline { 2 - 7 } & House of Representatives & 169 & 80.5 & 80.5 & 99.5 \\
\cline { 2 - 7 } & 4 & 1 & .5 & .5 & 100.0 \\
\cline { 2 - 7 } & Total & 210 & 100.0 & 100.0 & \\
\hline
\end{tabular}

\section{Source: Data from fieldwork}

The general consensus is that the House of Representative should be blamed for generating conflict and strained relationships between the Senate and itself unnecessarily. 169 respondents representing $80.5 \%$ was of the opinion that the House should be blamed. The argument the House advanced in scuttling the inauguration in the co-chairmanship of the committee was neither constitutional nor canvassed and approved as part of the programmes of the constitution review committee. The unwarranted competition and struggle for personal allowance and other economic interests hinders the legislature from legislating for people's welfare. This is a clear case of greed, selfishness, and indifference to the yawning and expectations of Nigerians who had hoped so much on the National Assembly and the executive arm to turn around the Nigeria economy. Rather, they are enmeshed in the battle of ego and personal interest.

The issue of co-chairmanship, therefore, appears odd because there is always, in a meeting or and associations, a chairman. Furthermore, the assistant is known by different names; deputy chairman, vice chairman and alternate chairman. The meaning of deputy, vice or alternate is that when that chairman is absent, one of these other three names act as chairman unless he is absent from the meeting. And section 53(2) of the 1999 Nigerian constitution clearly defines the spheres of power and position of the joint legislative committee and of personality disputes among the leaders of the National Assembly. Ego problems associated with acquisitive instincts explain the fact that there is no substance in the issue of who is chairman of the Joint Constitution Review Committee.

The reason why the House of Representatives want to ensure that the title "co-chairman" is employed is to make sure that the chairman takes no decision without consulting the co-chairman. However, the chairman never takes any decisions. The committee does. This is because in parliamentary meetings, there is no situation where one person takes a decision. Issues in the National Assembly are decided by vote, not by chairman. As chairman of a Joint Constitutional Programmes, the chairman is a presiding officer. He sits down and arranges who talks next and puts the issue to vote. It is therefore an aberration to talk of co-chairman by the House of Representatives because decisions in the legislative houses are taken by a majority. Well, it seems that the members of the House see the position of a chairman as an executive position, but it is not an executive position. They are presiding positions to bring order into the decision-making process. ${ }^{13}$ Therefore, the concept of co-chairman is alien to legislative vocabulary and the issue under contention should 
not have arisen in the first place. The issue of co-chairman does not exist in the parliamentary dictionary, not even in the English lexicon.

4.2 The Bickering Between the two Chambers of the National Assembly over which of them will host the joint sitting for the 2010 budget presentation

The conflict between the two chambers of the National Assembly in November, 2009, again seems to be infantile and diversionary. This time it was over which of them will host the joint sitting for the president's budget presentation for 2010. The Senate argues that a joint session of both chambers to receive the presidential address on annual budgets is unconstitutional.

The Senate wanted the presentation to be done in its chamber while the House of Representatives argues that the tradition of budget presentation by the President is usually done in the chambers of House of Representatives. This has always been the convention to receive the budget in the House of Representatives. It is larger and the Senate President presides. Usually after the presentation of the budget by the President, the speaker gives a vote of thanks. This seems to be the tradition with countries operating bicameralism.

The mundane supremacy fight between the Senate and the House of Representatives does not show that the legislators appreciate their role, which is to make laws for the betterment of the country. Nigerian Federal lawmakers are perhaps the best paid in the world, yet they are turning out to be the least productive. The presentation was postponed owning to this face-off between the two chambers over the choice of venue to receive the president.

The Senate wanted the budget to be presented in the Red chamber of the Senate chamber, but this was opposed by the House of Representatives. The House insisted that it would not attend the session as parliamentary convention since 1999 to date dictated that the budget is presented to lawmakers in the House of Representatives, which has a larger chamber because it has 360 members. There are only 109 senators. The Senate's argument is that the venue is not stipulated anywhere in the 1999 constitution. I think there is noting constitutional about the venue of a joint session. It is not contained in any of the study rules, neither is it in the constitution. The idea of presenting the budget in a joint session is not even in the constitution.

What is in the constitution in sections 81(1) is that the President shall cause to be laid before the two chambers of the National Assembly a copy of the estimate of the appropriative bill for the following year. The Senate argues that there is no prescription in the constitution for a joint sitting. Section 53 of the 1999 constitution specifies who the chairman is when there is a joint sitting between the two chambers and the chairman has the prerogative to decide who performs what functions when that situation arises. It is not for anybody to dictate who gives vote of thanks. That is a normal procedural issue in the course of a joint session.

Since the inauguration of the sixth National Assembly over two years ago, the frosty relationship that has existed between the two chambers and their leaders has imparted most negatively on the quality of the enacted laws. It has stymied both the constitution review process and the Electoral Act amendment.

\subsection{Presentation of 2010 Budget to the National Assembly by President Yar'Adua}

\section{Section 81(1) of the 1999 constitution of the Federal Republic of Nigeria simply states that:}

The President shall cause to be prepared and laid before each House of the National Assembly, anytime, in each financial year, estimates of the revenue and expenditure of the federation of next financial year. ${ }^{14}$

In compliance with this provision of the constitution, the President had on November 3, 2009, written to the National Assembly craving their indulgence to grant him "the slot of 11.00 am on November 19 to formally address the joint session of the National Assembly on Budget 2010". ${ }^{15}$ The idea behind the early presentation of the Appropriation Bill is for the lawmakers who hold the approval power to expenditure to have enough time to go through the process of appropriation so that the executive arm of government can also execute the budget early enough in the following year.

Since 2007, the Senate and House of Representatives have only agreed on money bills, specifically Appropriation Bills. The House has 28 bills awaiting concurrence with the Senate while the Senate has 12 bills waiting for its concurrence. The reasons for approving appropriation bills are obvious and important. To be sure, it tends to support the personal and group pursuit of the legislators. For example in the 2010 appropriation bill the National Assembly plans to spend for themselves $\# 1.1$ billion on meals and refreshments. ${ }^{17}$ They also planned to spend $\# 15.1$ billion on honorarium and sitting allowances. In 2009 appropriation budget, the National Assembly was allocated \#59.8 million for refreshment 
and meals. To clear rats and mosquitoes from the House of Representatives section of the National Assembly complex \#100 million was voted. We can now see why before 2007 and since 2007 the Senate and House of Representatives have agreed on money bills, especially Appropriation Bills. This current scenario paints a picture that even the appropriation bills will soon be affected.

Personal desire of members of the House of Representatives has blindfolded them so that they desire to be placed on the same rung with Senators on the legislative leader. But they do not appreciate the fact that their colleagues in the Senate are ranked higher even on the protocol order. As the constitution places the Senate President as the chairman of any joint sitting so does it move him or the Senate President as chairman of the National Assembly. The Senate President is the chairman of National Assembly and in any joint sitting of the National Assembly where the Senate President is physically present, he presides. This is an age-long norm and conventions that have come to be accepted globally. Where the budget is presented is no way fundamental to the operations of the legislature. It is not even a constitutional matter.

Because of personal interest and ego, little issues of no importance are trivialized to make it important. President Yar'Adua then had to present 2010 budget by proxy, in separate sessions of the two Houses; thus aborting a 10-year-old tradition and convention of the presidential presentation of the budget to a joint session of the National Assembly. It was in the midst of this instability and bickering that the executive initial $\$ 4.1$ trillion proposition was padded by yet another A529 billion by the National Assembly which in the normal political process and going by the doctrine of separation of powers, ought to be limited to lawmaking. ${ }^{17}$ By this, Executive appropriates, while the National Assembly legislates.

However, over the years especially from 1999, the legislature has brazenly introduced concepts such as constituency projects, legislative offices and other amorphous terms to inject projects and consolidate their interests in the various appropriations with intent to muscle the executive into ceding part of its powers to it. It was based on the foregoing that the Acting President initially objected to the signing of 2010 budget before reversing himself.

In the 2010 the National Assembly was allocated a total of N127.7 billion out of which the House of Representatives will spend more than 22 billion on local and international travels. Senators on the other hand will spend about $\$ 6$ billion for the same purpose. ${ }^{18}$ The legislators however added another hefty allocation captured under the subhead; "Programmed Activities". Under this sub-head, the Senate got an allocation of \#9 billion while the House or Representatives was allocated the sum of $\$ 3.2$ billion. ${ }^{19}$

Table 4: The Conflict between the Senate and House of Representatives on the Joint Sitting for Presentation of 2010 Budget was based on?

\begin{tabular}{|l|c|c|c|c|c|}
\hline & $\begin{array}{c}\text { no } \\
\text { response }\end{array}$ & $\begin{array}{c}\text { Personal } \\
\text { ego }\end{array}$ & Arrogance & $\begin{array}{c}\text { Constitutional } \\
\text { ambiguity }\end{array}$ & $\begin{array}{c}\text { Lack of understanding } \\
\text { of their constitutional } \\
\text { role }\end{array}$ \\
\cline { 2 - 8 } $\begin{array}{l}\text { The conflict between the senate and House } \\
\text { of Representatives on the Joint sitting for } \\
\text { presentation of 2010 Budget was based on? }\end{array}$ & 6 & 6 & 1 & 12 & 13 \\
\hline Total & 132 & 17 & 6 & 7 & 10 \\
\hline
\end{tabular}

\begin{tabular}{|l|r|r|r|}
\hline \multicolumn{5}{|c|}{ Chi-Square Tests } \\
\hline & \multicolumn{1}{|c|}{ Value } & df & Asymp. Sig. (2-sided) \\
\hline Pearson Chi-Square & 67.604 & 4 & .000 \\
\hline Likelihood Ratio & 60.585 & 4 & .000 \\
\hline Linear-by-Linear Association & 61.373 & 1 & .000 \\
\hline N of Valid Cases & 210 & & \\
\hline a. 4 cells (40.0\%) have expected count less than 5. The minimum expected count is 1.27. \\
\hline
\end{tabular}


In this case, the above analysis output of the proposition that the conflict between the Senate and House of Representatives on the Joint sitting for presentation of 2010 Budget was based on either of the following, personal ego; arrogance; constitutional ambiguity; and lack of understanding of their constitutional role; clearly show that the significance value is so low that it is displayed as .000 , which means that it would appear that the two variables (that is the question and the responses) are, indeed, related. The significance value (two-sided Asymptotic Significance) has the information we are looking for in the sense that the lower the significance value, the less likely it is that the two variables are independent (unrelated).

\subsection{The Passage of 2008 Appropriation Bill}

Another area of conflict between the Senate and the House of Representatives was the passage of the 2008 Appropriation Bill as submitted by the President in 2007. The National Assembly had pledged a commitment at its inauguration in 2007, to make sure National budgets were always passed on time to make for easier implementation by the executive. It was a commitment that the Senate and the House of Representatives as well as the executive pledged and made it a contract. They recognized the damage delays in the passage of appropriation bills had caused governments in the past, the poor public image it has heated for the National Assembly and the absence of dividends of good governance that Nigerians were denied of. Since the inception of the sixth session in 2007, only 16 bills have been passed by the National Assembly. These included yearly budgets. Only 11 of the bills have received Presidential assent. After the presentation of 2008 budget proposals by President Umaru Yar'Adua in September 11, 2007, the Speaker of House of Representatives pledged the House commitment to a speedy passage of the budget, declaring that it was only under such circumstance that governance could be meaningful to the people. The Senate on its part equally expressed such sentiments when on November 18, 2007 the Senate said it would not relent on working for the earliest passage of the budget. This commitment was to ensure that the appropriation bill becomes operational by January, 2008.

Incidentally, days into the 2008 financial year, the budget was yet to be passed. It seems that the two legislative chambers have appeared to have forgotten all they pledge, relegating all that concerned the budget to the background, as they quarreled over matters of constitution review. Each house blamed the other for delaying the passage of the budget. The Senate on its part had come out in unmistakable terms to accuse the House of Representatives of Scuttling the early passage of the budget. They blamed the House for staling development and progress of the country.

\section{Conclusion}

The underdevelopment of Nigeria and the conflictive relationship between the Senate and the House of Representatives are anchored on the problem of private interest and self-serving leaders who are in public institutions to satisfy their private aggrandizement and self glorification. Essentially, Nigerian politicians seek public offices only for personal interest rather than improved services to the Nigerian nation. That the legislators' actions have affected and paralyzed government activities cannot be over emphasized. It has in particular jeopardized actions on the most pressing assignment of the Joint Committee on Constitution Review as a result of power tussle among the presiding officers of the National Assembly.

The current face-off over who is superior between the two chambers of the National Assembly, the Senate and House of Representatives, is a misplacement of priority by those elected to represent and serve the people of Nigeria. The squabble over obvious trivial matters explains the nature and characters of the member of the National Assembly in particular and the governing class in general. Their engagement is absurd, sublime and ridiculous squabble shows they have nothing to offer the nation. This has questioned the legislator's sense of responsibility and patriotism because of legal and moral arguments being espoused by both the Senate and the House.

Democratic government, are made by people. Their forms are influenced greatly by impersonal economic, social, cultural and political factors. For democracy to succeed in Nigeria, people operating organs of government must create enduring institutions and norms, adopt procedure and institute policies that will command the support of the citizens. One digressing influence is the fact that the members of the Nigerian ruling class do not control the productive forces of society and as such are not productive. The Nigerian state and its governing class lack an economic base for effective governance. They are parasite and depend on the state power for private capital accumulation. And because they are parasitic in nature, there is very serious struggle and competition for the control of the state power and those who have acquired it now use it for personal goals. 
The struggle and competition for the acquisition of the state power and private capital accumulation translates to the struggle and conflictive relationships between the Senate and the House of Representatives in Nigeria. This is because state power has remained attractive since it solely provides quick economic rewards for those who have acquired state power. Thus, transformative legislature is gradually eluding Nigerian legislative House. To be sure, they have become unable to act as independent initiators of policies and to reconcile as well as channel societal demands and conflicts. It has equally made socio-economic and political reformation anchored on justice, equity and accountability impossible.

\section{Acknowledgements}

We acknowledge the grant offered to us by American Political Science Association which was largely supported by the Mellon Foundation for the conduct of the study.

\section{REFERENCES}

Amaechi, I. (2009).As Lawmakers Dance Naked, Daily Independent, November 2

Adetutu, F, Tunde, O.Iwuchukwu, C.and Negedu, B (2009).2010 Budget, Daily Independent, November 21

Bacon, D.C; Davidson, R.H; and Keller, M. (eds) (1995). Encyclopedia of the United states Congress, Oxford: Simon and Scumbler.

Boyton, G. R. and Kim, C. L. (1975) Legislature Systems in Developing Countries, North Carolina: Duke University Press

Davies, A. E. (2004). The Role of the Legislature in Fostering an Efficient System of Public Finance, in Fajingbesi, A.A. and Taiwo, I.O

(eds), Fiscal Federalism and Democratic Governance in Nigeria. Ibadan: National Centre for Economic Management and Administration

Ebulu, S (2010) Budget: How Presidency and National Assembly Should Collaborate, The Nation May 3

Federal Republic of Nigeria (1999) Constitution of the Federal Republic of Nigeria, Lagos: Spokane Communications Ltd

Joseph, R. (1987). Democracy and Prebendal Politics in Nigeria: The Rise and Fall of the Second Republic, Ibadan: Ibadan University Press

Mackintosh, J.P. (1966), Nigerian Government and Politics, Evanston: Northwestern University Press

Maduabuchi, E. (2009). Dowsing the Legislative Squabble, Sunday Independent, February 1.

Myers, D.G. (2007). ABC Psychology, New York: Worth Publishers

Nwabueze, B. (2009). Reps. Walk-Out on JCCR Retreat, Sunday Independent, February 1.

Nwabueze, B. (1985). Nigeria's Second Experiment in Constitutional Democracy, London: Hurst and Company.

Onuorah, M, Daniel, A, Ogbodo, J. and Jimo, A. (2009).Yar'Adua Presents 2010 Budget by Proxy, The Guardian Wednesday November 25

Odunuga, Y.and Badalona, J (2009).Presidency Votes 28b for Feeding and Others, The Nation, Tuesday November 26

Sabine G. and Thorson T. (1973) History of Political Theory, Oxford: IBH Publishing Company

The Starlite(2012) Nigerian Senator Earns More than Barrack Obama, The Starlite, Monday August13

Zwingina, J (2009). Senate/Reps Party Controversy, Sunday Independent, February 1.

\section{NOTES}

1. Davies 2004.

2. Federal Republic of Nigeria 1999, 2.

3. Sabine and Thorson 1973, 513.

4. Joseph 1987.

5. Myers 2007.

6. The Starlite 2012, 12.

7. Ibid.

8. Ibid.

9. Ibid.

10. BusinessDay 2010, 4.

11. Nigerian Tribune 2010, 1.

12. Nwabueze 2009, B9.

13. Zwingina 2009, B2.

14. Federal Republic of Nigeria 1999, 37.

15. Amaechi 2009, 48.

16. Odunuga and Babalola 2009, 1 .

17. Ebulu 2010, 24.

18. Onuorah et al 2009, 2.

19. Ibid. 
E-ISSN 2039-2117

ISSN 2039-9340
Mediterranean Journal of Social Sciences MCSER Publishing, Rome-Italy
Vol 5 No 1 January 2014 